\title{
DOKUMENT MYŚLI OTWARTEJ. STUDIA POLESKIE JÓZEFA OBRĘBSKIEGO A ROZWAŻANIA O GRUPACH ETNICZNYCH I STOSUNKACH NARODOWOŚCIOWYCH W POLSKIEJ ETNOLOGII I SOCJOLOGII
}

\author{
A DOCUMENT OF OPEN THOUGHT: \\ JÓZEF OBRĘBSKI'S STUDIES ON THE POLESIE \\ REGION AND DEBATES ON ETHNIC GROUPS \\ AND NATIONALITY RELATIONS IN POLISH \\ ETHNOLOGY AND SOCIOLOGY
}

Abstract

This article attempts to reconstruct and examine the concept of the ethnic diversity and nationalization process found in the writings of the Polish anthropologist and sociologist Józef Obrębski (1905-1967). It will be argued that Obrębski's view on ethnic diversity and the nationalization allowed him not only to conceive of a highly original idea of nation-building process but also maintain a critical distance from the two forms of reflection and practice- "investigative modalities"-influential in the field of ethnic and national studies in prewar as well as in postwar Poland: "ethnogeography" and the "sociology of nation". In the same time this text aims at underscoring usefulness of Obrębski's ideas for contemporary analysis. Close reading of his works provides us with fresh tools for the ethnographic processual examination of the nationalization policies. It draws special attention to the process of nationalization of local populations, highlighting various and contradictory consequences of nationalization process: integration and homogenisation on the one hand and exclusions of minorities and class hierarchization of people on the other.

Key words: Józef Obrębski; ethnicity; nationalization; nationbuilding process; Polesie region; Polish ethnology and sociology

\author{
JÓZEF OBRĘBSKI \\ ETNOSOCJOLOGIA \\ POLESIE WCZORAJ I DZIŚ
}

MARCIN LUBAŚ

Uniwersytet Jagielloński, Kraków

E-mail: marcin.lubas@uj.edu.pl http://orcid.org/0000-0002-2065-3696

CITATION: Lubaś, M. (2019) Dokument myśli otwartej. Studia poleskie Józefa Obrębskiego a rozważania o grupach etnicznych i stosunkach narodowościowych w polskiej etnologii i socjologii. Sprawy Narodowościowe. Seria nowa, 2019(51). https://doi.org/10.11649/sn.1895

This work was supported by the author's own resources. No competing interests have been declared.

This is an Open Access article distributed under the terms of the Creative Commons Attribution 3.0 PL License (creativecommons.org/licenses/by/3.0/pl/), which permits redistribution, commercial and non-commercial, provided that the article is properly cited. (C) The Author(s) 2019

Publisher: Institute of Slavic Studies, Polish Academy of Sciences 
Celem artykułu jest omówienie koncepcji grup etnicznych i procesów unaradawiania wyłaniających się z prac Józefa Obrębskiego. W szczególności chodzi o wykazanie, że swoimi badaniami na Polesiu Obrębski wniósł niezwykle oryginalny wkład w badania stosunków etnicznych i narodowościowych, podając jednocześnie w wątpliwość niektóre założenia tkwiące u podstaw dwu modalności dociekań obecnych w polskich badaniach nad etnicznością i kwestiami narodowymi: czyli etnogeografii oraz socjologii narodu. Jednocześnie tekst służy ukazaniu aktualności propozycji teoretycznych i metodologicznych Obrębskiego w badaniach stosunków etnicznych i narodowościowych. Lektura pism Obrębskiego dostarcza perspektywy umożliwiającej nie tylko krytykę nacjonalizmu metodologicznego, ale również daje podstawy do procesualnej, etnograficznej - uwzględniającej mikrostrukturalny wymiar władzy - analizy zjawisk etnicznych i stosunków narodowościowych. Otwiera to możliwość badania różnych niekiedy odmiennych i sprzecznych ze sobą efektów procesów unaradawiania, zarówno integracji i wyrównywania szans jak też konfliktów i wykluczenia społecznego.

Słowa klu c zow e: Józef Obrębski; etniczność; unarodowienie; Polesie; socjologia; etnologia

\section{WPROWADZENIE}

Ózef Obrębski (1905-1967) pozostaje jednym z najbardziej niezwykłych polskich badaczy i teoretyków stosunków etnicznych i narodowościowych. Jak wykazywała Anna Engelking, Obrębski połączył umiejętnie w swoich pracach teorię zmiany społecznej zawartą w dziełach Floriana Znanieckiego i jego zwolenników z metodą funkcjonalną, którą upowszechniał z Londynu Bronisław Malinowski, oraz skrupulatnością i rzetelnością badawczą swego krakowskiego mistrza Kazimierza Moszyńskiego (por. Engelking, 2007b, ss. 10-11, 20-25). Zarazem dzieło Józefa Obrębskiego znane nam daleko pełniej dzięki ogromnemu wysitkowi redakcyjnemu i interpretacji wspomnianej Anny Engelking (zob. Engelking, 2003, 2005, 2006, 2007b) jest wytworem myśli nie tylko syntetyzującej, ale ujawniającej własny, bardzo oryginalny wkład teoretyczny i metodologiczny wymykający się schematom, otwierający obszary dociekań, zachęcający do stawiania nowych i śmiałych pytań.

Trudno rozpatrywać idee Obrębskiego w oderwaniu od recepcji jego dorobku naukowego. Wiadomo, że należy on do uczonych stopniowo odkrywanych dopiero po śmierci. Jego kariera naukowa potoczyła się niefortunnie ${ }^{1}$. Nie jest z pewnością autorem ignorowanym czy zapomnianym, jego prace nie należą jednak do ścisłego kanonu tekstów dotyczących narodu, nacjonalizmu, grup etnicznych, procesów narodotwórczych². Stwierdzenie Anny Kutrzeby-Pojnarowej, iż Obrębski to „[...] teoretyk związany z nowymi kierunkami w nauce obcej” (Kutrzeba-Pojnarowa, 1979, s. 72), który „[...] stanowi szkołę sam dla siebie" (Kutrzeba-Pojnarowa, 1979, s. 75) wskazuje nie tylko na niezależność intelektualną autora Polesia archaicznego, ale również spektralną obecność dorobku Obrębskiego w pracach badaczy pokolenia, do którego należał. Dopiero w następnych naukowych generacjach zaczęto dostrzegać wyraźniej nowatorstwo koncepcji wypracowa-

\section{-.....}

Bogatym zasobem wiedzy o biografii naukowej Józefa Obrębskiego są opracowania autorstwa Anny Engelking (Engelking 2003, 2005, 2007), a także - chociaż w daleko skromniejszym zakresie - teksty Joela Halperna $(1976,2002)$.

2 Pojedyncze teksty Obrębskiego są dostępne w antologiach i wyborach tekstów (Burszta, Nowak, \& Wawruch, 2002; Szacki, 1995). 
nych przez Obrębskiego podczas badań w Macedonii i na Polesiu w latach trzydziestych XX wieku.

Można z pożytkiem rozprawiać o przyczynach, dla których Obrębski nie stał się za życia główną - obok Jana Stanisława Bystronia, Floriana Znanieckiego, Stanisława Ossowskiego czy Józefa Chałasińskiego - postacią w polskich badaniach nad narodem i etnicznością. Należy także - w kontekście nieudanej kariery naukowej Obrębskiego i marginalizacji jego dorobku w pewnym okresie - jasno postawić pytanie o relacje między państwem, polityką unaradawiania a etnologiczną i socjologiczną praktyką naukową ${ }^{3}$. Nie mogę tu tych bardzo ważnych kwestii ignorować, jednak w artykule niniejszym stawiam sobie nieco inne zadanie 4 . Po pierwsze, chciałbym dowieść, że koncepcje Obrębskiego powstałe w oparciu o badania poleskie zawierały idee prawdziwie przełomowe, uderzające w domyślne założenia ówczesnego myślenia naukowego i otwierającej zarazem przed aktywnością badawczą nowe możliwości. Dokładniej rzecz formułując, sądzę, że Obrębski podał w wątpliwość niektóre przesłanki, na których opierały się milcząco dwie, by użyć określenia antropologa Bernarda Cohna, "modalności dociekań" stosowanych w polskiej nauce przed i po II wojnie światowej (Cohn, 1996, s. 5). Owe modalności to z jednej strony tzw. etnogeografia i kartografia etnograficzna w etnologii, z drugiej zaś tzw. socjologia narodu. U podstaw obu tych ujęć mimo ewidentnych między nimi różnic legło założenie o obiektywnym istnieniu grup narodowych i etnicznych opartych na wspólnej kulturze, świadomości, więzi i terytorium. Obrębski, który podstawą swej koncepcji uczynił ideę subiektywnego poczucia przynależności grupowej, nie odwoływał się do pojęcia więzi i wspólnoty, lecz wyobrażeń, instytucji i działań pociągających asymilacje lub dysymilacje wychodził zdecydowanie poza aksjomaty badań etnologicznych i socjologicznych swej epoki.

Po wtóre, będą dążył do wykazania, że wywrotowe idee Obrębskiego są aktualne po dziś dzień. Przy tym jest to aktualność wieloaspektowa. Nie uda mi się wyczerpują-

\section{- •. •}

3 Pilnym zadaniem pozostaje kompleksowa analiza historii nauk historycznych, etnologii, socjologii w Polsce uwzględniająca zmienną rolę przedstawicieli i przedstawicielek tych dziedzin w tworzeniu i realizacji prowadzonego przez polski aparat państwowy w różnych okresach projektu narodotwórczego i polonizacyjnego.

4 Aby uniknąć niejasności, dodam, że analiza niniejsza jest przyczynkiem z zakresu tak zwanej systematyki teorii, nie zaś historii idei czy socjologii wiedzy. Swego czasu socjolog Robert Merton (1982), a także historyk antropologii George Stocking Jr. (1968) poddali systematykę teorii krytyce. Merton zauważył, że krytyczne omówienia dawniejszych dokonań teoretycznych uchodzą niesłusznie za rodzaj historii socjologii. Tymczasem z wyspecjalizowaną historią procesów poznania naukowego mają niewiele wspólnego, gdyż opisują, porównują, klasyfikują i oceniają gotowy efekt pracy naukowej w postaci utrwalonych w piśmie opracowań, artykułów, podręczników, traktatów, nie interesując się specjalnie najbardziej wartościowym z historycznego punktu widzenia materiałem źródłowym pozwalającym śledzić proces dochodzenia do określonych ustaleń (Merton, 1982: 28). Ze swej strony Stocking zarzuca systematyce, którą określa podejściem prezentystycznym, iż powiela wigowski mit historyczny, polegający na relacjonowaniu przebiegu wydarzeń w sposób stronniczy, tj. biorąc w opowiadaniu stronę jednego tylko z aktorów procesu, przeważnie tego który w momencie pisania historii jawi się jako siła zwycięska i dominująca (Stocking, 1968: 3). Podobnie jak Merton Stocking uznaje, że ów prezentyzm systematyki teorii zapoznaje procesualny charakter poznania, zamiast podążać za procesami myślowymi skupia się na gotowych efektach tych procesów (1968: 5). Bardziej niż podążaniem za procesem zmian zachodzacych w nauce jest zainteresowany przeprowadzaną - nie wprost - legitymizacją pewnego aktualnego sposobu jej uprawiania. Zarzuty stawiane systematyce nie unieważniaja jej jako przedsięwzięcia, ale wskazuja warsztatowe ograniczenia systematyki jako podejścia do analizy dorobku naukowego minionych pokoleń. Systematyka w istocie nie posługuje się narzędziami pozwalającymi odtworzyć przebieg procesu poznawczego, którego następstwem jest określony naukowy wytwór, ale umożliwia ocenę przydatności tego wytworu dla współczesnych dociekań. Zarzut powielania mitu wigowskiego można postawić również wyspecjalizowanym historykom dyscyplin pokroju Stockinga, gdyż w swoich opisach biorą stronę i dokonują legitymizacji jednego ze sposobów relacjonowania historii antropologii, inspirowanego - powiedzmy - pracami Thomasa Kuhna. Przychylam sie do opinii Henriki Kuklick (2008), iż historia idei i systematyka teorii to projekty wobec siebie komplementarne a nie nawzajem się wykluczające. Historia idei powściąga roszczenia systematyki, uświadamia jej, iż jest dezaktualizującą się z czasem aktywnością uwierzytelniającą nie mniej dezaktualizujące się teorie. Historia idei potrzebuje takowej systematyki, która jest dla tej pierwszej przewodnikiem po teraźniejszości teorii, wskazuje co w materiale historycznym jest teoretycznie doniosłe i ciekawe. 
co jej tu przedstawić, niemniej należy, jak sądzę, zwrócić uwagę na to, że w pismach Obrębskiego odnajdujemy wyraźny zarys koncepcji procesów unaradawiania zbiorowości ludzkich. Samo zagadnienie unaradawiania mas ludowych było oczywiście podejmowane przez intelektualnych mentorów młodego Józefa - takich jak Bystroń, Znaniecki i Chałasiński. Niemniej analizy Obrębskiego wyróżnia wyczulenie na rolę aparatów władzy, szczególnie aparatów władzy państwowej, oraz stosunków klasowych w upowszechnianiu ideologii nacjonalistycznych, zrozumienie ambiwalencji i moralnej niejednoznaczności procesów unaradawiania, w końcu zwrócenie uwagi na zróżnicowanie efektów polityki unaradawiania, która prowadzi nie tylko do integrowania szerszych zbiorowości, ale również może skutkować podziałem, wykluczeniem i dyskryminowaniem ich części.

Unarodowienie jawi się zatem w jego koncepcji jako proces daleko bardziej złożony niż nieuchronne i dobroczynne w skutkach wtapianie się mas ludowych w społeczeństwo ogólnonarodowe. Patrzy on na unarodowienie nie z perspektywy uprzywilejowanej elity, ale klas i grup podporządkowanych, dostrzega w całej wyrazistości władzę i przemoc, jakie unarodowienie za sobą pociąga. Wydaje się zatem całkiem współczesnym badaczom nacjonalizmu i etniczności okresu najnowszego (Brubaker, 1992, 2004; Malašević, 2013; E. Weber, 1976; Wimmer, 2002, 2019).

Rozważania wokół osoby i prac Obrębskiego skłaniają do namysłu nad procesami przemian zachodzącymi w nauce. Lektura dzieła tego autora nieustanie prowadzi do porównań. Idee Obrębskiego zdają się wchodzić w zastanawiający dialog z koncepcjami sformułowanymi znacznie później i niezależnie przez teoretyków tak różnych jak Fredrik Barth (Barth, 2004), Franz Fanon (Fanon, 1967), Ranajit Guha (Guha, 2009), Edward Said (Said, 2005), James Scott (Scott, 1985, 1990).

Czy należy zatem widzieć w Obrębskim twórce avant la lettre, antycypującego przyszły rozwój nauki? Sądzę, że Obrębski był przede wszystkim badaczem otwartym, niekoniunkturalnym. Jego wywód jest spójny i rzeczowy, a jednocześnie badania ukazują nowe możliwości i kierunki poszukiwań, tam, gdzie inni operują utrwalonym i aprobowanym schematem, rozumowaniem, którego każdy krok jest już znany, uczony ten dostrzegał nieoczywistość i nieostateczność wiedzy zastanej oraz rozumowań, na których się ona opiera, potrzebę rewidowania poglądów w świetle nowych ustaleń empirycznych i kontynuowania poszukiwań badawczych.

Myśl taka, chociaż niepokojąca i inspirująca, niełatwo jest przyswajalna w całości. Nie można jej ująć w doktrynę. Koncepcje Obrębskiego przyjmowano powoli, we fragmentach i z niemałymi oporami, wpływ jego idei zdaje się bardziej uchwytny jedynie pod warunkiem uwzględnienia długich serii zdarzeń. Dzieło to wpisuje się w osobliwie rozciągnięty w czasie proces, "długą rewolucję”, by użyć tytułu książki Raymonda Williamsa (Williams, 2011), czyli wielogeneracyjny, wieloaspektowy i wcale nie-nieuchronny ciąg przeobrażeń zachodzących w polskiej nauce o narodzie i mniejszościach.

Dalsze rozważania zostały podzielone następująco. Najpierw chciałbym omówić - siłą rzeczy skrótowo - wyłaniającą się z analiz Obrębskiego koncepcję zróżnicowań i grup etnicznych. Mam zamiar pokazać jej niezgodność z wieloma - chociaż nie wszystkimi badaniami prowadzonymi pod szyldem etnogeografii. Co więcej, postaram się zademonstrować, że krytyczne ostrze koncepcji Obrębskiego było przez część etnologów zajmujących się mapowaniem i atlasami etnograficznymi stępiane. W kolejnej części wywodu omówię wypracowany przez Obrębskiego niezwykle ciekawy wariant koncepcji unaradawiania ludu. Spróbuję również zestawić poglądy Obrębskiego z koncepcjami luminarzy socjologii narodu: Józefa Chałasińskiego, Stanisława Ossowskiego, Stefana Nowa- 
kowskiego. Nie ulega dla mnie wątpliwości, że badacze ci nie odwoływali się w swoich pracach empirycznych do programu Obrębskiego. Zarazem uważam, że program ten nie mieścił się w całości w ramach pojęciowych socjologicznych badań nad narodem jego epoki. Interesowała go przede wszystkim dynamika życia narodowego, a nie refleksja nad abstrakcyjnymi całościami takimi jak naród, więź czy kultura narodowa. Obrębski bacznie przyglądał się procesom kształtującym poczucie odrębności grupowej, wizerunkom grup. Ideologię narodową rozumiał jako zespół działań i praktyk, a nie oderwanych od codziennego życia abstrakcyjnych idei i wyobrażeń. Co istotne, nie traktował unarodowienia jako zbawiennej siły integrującej na nowo społeczeństwo, ale jako proces ambiwalentny, wielokierunkowy, prowadzący również do wykluczenia i nowych nierówności społecznych. Na koniec wrócę do kwestii aktualności prac Obrębskiego. Wskażę przynajmniej niektóre obszary refleksji obecne w jego dziele stanowiące realnie lub potencjalnie źródło inspiracji dla współczesnego namysłu teoretycznego i badawczego w socjologii oraz antropologii i etnografii stosunków etnicznych i narodowościowych.

\section{KONCEPCJA GRUP ETNICZNYCH I POLSKA ETNOGEOGRAFIA}

Prowadzone w latach 1934-1936 i w roku 1937 wyprawy badawcze Obrębskiego i jego współpracowników (zob. Engelking, 2007b, ss. 13-20) na Polesie zaowocowały stworzeniem koncepcji zróżnicowania etnicznego i grup etnicznych sformułowanej w czterech artykułach opublikowanych po raz pierwszy w roku 1936 (Obrębski, 2005, 2007) oraz maszynopisach wydanych drukiem w redakcji naukowej Anny Engelking (Obrębski, 2007).

Jak pokazuje w analizach dorobku Obrębskiego Anna Engelking, znajdowat się on w okresie formułowania swojej koncepcji pod silnym wpływem dwu orientacji badawczych. Z jednej strony źródłem inspiracji była dlań metoda funkcjonalna Bronisława Malinowskiego, z drugiej socjologia humanistyczna Znanieckiego i jego zwolenników (Chałasińskiego, Stanisława Orsiniego-Rozenberga), w szczególności analiza przemiany klasy chłopskiej prowadzona przez tego pierwszego oraz Williama I. Thomasa $w$ dziele uznawanym za jedną z najwybitniejszych książek polskiej socjologii XX wieku, pracy Chłop polski w Europie i Ameryce (zob. Engelking, 2007b, ss. 19-24). Obrębski podzielał zdecydowanie zainteresowanie autorów (Thomas, Znaniecki, 1976) analizą zmiany społecznej, a konkretniej badaniem dezorganizacji i reorganizacji społeczności chłopskich i ludowych w warunkach głębokich przeobrażeń społecznych i kulturowych (czyli migracji, przemian technologicznych i stosunków gospodarczych, przeobrażeń struktur życia rodzinnego, nowych odmian życia religijnego, formowania państw narodowych, zaostrzających się konfliktów klasowych i wielu innych). Przedmiotem refleksji Obrębskiego stały się m.in. przemiany świadomości grupowej zachodzące w społecznościach chłopskich w warunkach stanowienia państwa narodowego i jednocześnie postępującej i coraz głębszej dezorganizacji dotychczasowych porządków społecznych na wsi.

Obrębski przyjmuje, jak wiadomo, że podstawą istnienia grupy etnicznej jest subiektywne poczucie przynależności/odrębności wyrażane przez członków społeczności ludowych. A zatem grupy etniczne to, jak powiada twory wyobrażeniowe, nie konkretne (Obrębski, 2005, s. 157, 2007, s. 260). Zarazem zakres pojęcia grupy etnicznej jest u Obrębskiego swoisty. Grupa etniczna jest podziałem społeczności ludowych pozbawionych jednorodnej i zwartej organizacji, a także poczucia wspólnego pochodzenia (Obrębski, 
2005, ss. 158-159). Niezmiernie interesujące, że Obrębski rozpatruje dalej ideę grupy etnicznej fenomenologicznie, biorąc pod uwage świat codziennego doświadczenia i naturalnego nastawienia osób grupę taką tworzących, zatem „(...) grupa etniczna (...) to ten krąg, w którym sposób mówienia, utarte zwroty i powiedzenia, wykrzykniki i żarty, sposób w jaki manifestowane są reakcje emocjonalne, sposób bycia i działania nikogo nie dziwi, nie razi; gdzie te zwyczaje osobiste jednostki traktowane są jako naturalne i odpowiednie (...)" (Obrębski, 2005, s. 162); tam zaś, gdzie tych cech doświadczenia brak, gdzie pojawia się niepewność, obcość, cudaczność, tam zaczyna się świat grupy odrębnej czy obcej (Obrębski, 2005, s. 162).

Idąc przeto za teorią Znanieckiego i własnym doświadczeniem badawczym, Obrębski dowodził więc, że to kontakt między grupami stwarza warunki do wykształcenia się owego poczucia odrębności/przynależności, dopiero bowiem wejście w relacje z osobami należącymi do innych niż rodzima społeczności uświadamia ludziom istotność cech kulturowych różniących ich od innych sąsiednich społeczności, otwiera przed nimi poczucie i doświadczenie obcości i dziwaczności języka, obyczajów, przekonań (Obrębski, 2005, s. 161, 2007, ss. 188-189; Znaniecki, 1990).

Poczucie odrębności wyrażane jest, zdaniem Obrębskiego, w określonych konstrukcjach pojęciowych, w szczególności wizerunkach grupy obcej i własnej (Obrębski, 2007, s. 189). Na obraz ten składa się wiele elementów: typowy ubiór i wygląd zewnętrzny, mowa "(...) swoi są ci, którzy umieją wziąć udział w grze stereotypowych zwrotów i konwencjonalnych formuł (...)" (Obrębski, 2007, s. 190), cechy fenotypowe a także psychiczne, jak również typowy dla grupy sposób utrzymania, poziom życia, rozrywki. Wizerunek jest projekcją wyobrażeń grupy o sąsiadach, stereotypem, czyli obrazem, "(...) w który grupa jakaś włącza swoje uprzedzenia i wyraża irracjonalne podstawy sympatii lub niechęci wobec grupy obcej" (Obrębski, 2007, s. 191).

Jednocześnie obraz grupy obcej stanowi inwersję wizerunku grupy rodzimej. Tym co konstytuuje, wedle Obrębskiego, grupę etniczną jest właśnie jej obraz innych grup, a nie obraz grupy własnej czy całokształt zasobów kulturowych tej grupy (Obrębski, 2007, s. 190). Czyli jak pisze Obrębski: „(...) O rzeczywistości wyobrażeniowej grupy etnicznej decydują więc nie tyle jej własne i samorodne wyobrażenia o sobie, ile jej wyobrażenia o sąsiednich grupach etnicznych i wyobrażeniach tych grup o niej" (Obrębski, 2005, s. 163). Ta intrygująca idea przywodzi na myśl późniejsze, sformułowane niezależnie, tezy Fredrika Bartha o roli dychotomii etnicznych, czyli tzw. granic etnicznych w podtrzymywaniu istnienia grup (Barth, 2004, s. 353).

Wizerunek grup obcych i własnej nie jest zdaniem Obrębskiego niezmienny i jednopostaciowy. Przyjmuje różne oblicza i podciąga się podeń różne treści w zależności od miejsca kontaktu między grupami etnicznymi społeczności ludowych. Poleszucy, argumentował Obrębski w oparciu o liczne przykłady, nie podzielali jednego wizerunku własnej grupy, wykorzystywali negatywny wizerunek swojej grupy tworzony przez sąsiednie grupy na użytek stosunków i podziałów wewnętrznych (Obrębski, 2007, ss. 209-210). Jednocześnie ich obraz grup sąsiednich stanowił na ogół „pozytyw” owego negatywnego obrazu własnego. W efekcie struktura etniczna Polesia okazywała się mieć charakter polimorficzny, dynamiczny i luźny (Obrębski, 2007, ss. 270-271). Nie istnieje tu łącząca ludzi w jedność więź ani wspólna podzielana przez członków grupy wizja własnej odrębności. Poleszucy to grupa etniczna znajdująca się w fazie rozpadowej.

Przełomowym założeniem teoretycznym i metodologicznym Obrębskiego było stwierdzenie, że budulcem relacji grupowych jest subiektywne poczucie przynależności do 
określonej grupy. Jak powiedziano wyżej, Obrębski szukał podstaw dla owego poczucia odrębności w relacjach międzygrupowych i ucieleśnionym doświadczeniu międzygrupowych różnic kulturowych wyrażanych w języku poprzez wyobrażenia, kategoryzacje, obrazy. Ten jednoznaczny pogląd sytuował Obrębskiego w opozycji do wielu badaczy etnologów zajmujących się etnogeografią, próbujących wytyczać granice etniczne w oparciu o analizę przestrzennej dystrybucji określonych praktyk, artefaktów i wierzeń. Niektórzy polscy etnografowie (m.in. Jan Stanisław Bystroń, Jan Czekanowski, Adam Fischer, Józef Gajek) podobnie jak językoznawcy-dialektolodzy przedstawiali zróżnicowania i podziały grup etnicznych w kategoriach przestrzennych zasięgów określonych cech kulturowych. Pisano zatem o polskich półwyspach i wyspach (Fischer, 1926, s. 10). Nawet Bystroń, skądinąd krytyczny wobec etnogeografii, uważał, że mapowanie jest jedyną, chociaż wysoce zawodną, metodą wytyczania granic polskiego terytorium etnograficznego (Bystroń, 1926, s. 109). Również po wojnie badacze tacy jak Gajek uznawali, że mapowanie przestrzennych zasięgów występowania cech kulturowych (elementów kultury materialnej, wierzeń i praktyk) może służyć opisaniu zespołu faktów kulturowych, charakterystycznych w przeszłości lub obecnie dla polskiej kultury ludowej oraz stanowiących czynnik wiążący Polskę w jedną całość etniczną (zob. Kłodnicki, Pieńczak, \& Koźmińska, 2017, s. 26).

Obrębski nie był, jak wiadomo, jedynym badaczem kwestionującym wyprowadzanie wniosków na temat podziałów na grupy etniczne i narody według przestrzennej dystrybucji cech inwentarza kulturowego. Podobny pogląd głosit Kazimierz Moszyński (por. Benedyktowicz, 2000; Engelking, 2012a; Kutrzeba-Pojnarowa, 1979). Teoretyczne przesłanki, na których opierał swą krytykę kartografii etnograficznej Obrębski, były jednak inne niż u Moszyńskiego. Inaczej niż Moszyński Obrębski interesował się bowiem nie długim procesem ewolucji kultury, lecz bardziej współczesnymi czy niedawnymi przemianami świadomości społeczności wiejskich.

W 1936 roku Obrębski opublikował w czasopiśmie "Sprawy Narodowościowe” krótką, za to niezwykle krytyczną recenzję niewielkiej książki autorstwa Jana Falkowskiego i Bazylego Pasznyckiego Na pograniczu temkowsko-bojkowskiem. Zarys etnograficzny (Falkowski \& Pasznycki, 1935). Obrębski przeprowadził w tekście zdecydowany atak na przyjęty przez Falkowskiego i jego współpracownika Pasznyckiego sposób wytyczania granic między grupami Łemków i Bojków w oparciu o metode etnogeograficzną. Recenzent zarzucił autorom całkowite pominięcie czegoś, co nazwał socjologicznym aspektem zróżnicowań etnicznych, czyli świadomości etnicznej członków tych grup i subiektywnego poczucia odrębności etnicznej występującego pomiędzy ich członkami (Obrębski, 2006, ss. 169-170). Recenzja i publikowane przez Obrębskiego w tym samym czasie artykuły na temat grup etnicznych wywołały interesującą dyskusję w polskiej etnologii.

Główny autor dzieła, Falkowski, odpowiedział na polemiczny tekst Obrębskiego, dowodząc, że wykorzystał poczucie odrębności etnicznej ujawniane przez członków grup jako dodatkowe i pomocnicze kryterium wytyczania granic między Łemkami a Bojkami. Oskarżył też Obrębskiego o przenoszenie na grunt badań etnologicznych podejścia socjologów (Falkowski, 2006, ss. 171-172). Wyraził jednocześnie zdziwienie, że Obrębski, niegdyś student etnografii, posługuje się takim właściwym innej nauce podejściem (Falkowski, 2006, ss. 171-172). Falkowski pominął jednak, jak się zdaje, sedno uwag Obrębskiego. Zdawał się przyjmować, że Obrębski stara się pogodzić jakoś wzajemnie świadectwa dotyczące poczucia przynależności/odrębności z klasycznymi danymi wykorzystywanymi w etnogeografii. Tymczasem uwagi Obrębskiego miały dalej idące implikacje. W istocie chodziło o za- 
kwestionowanie idei wyprowadzania na podstawie danych o dystrybucji cech inwentarza kulturowego jakichkolwiek wniosków odnośnie do podziału na grupy etniczne.

Co ciekawe, dyskusja na temat zarzutów Obrębskiego była kontynuowana już po wojnie (chociaż bez jego udziału). Jeden z badaczy Łemkowszyzny Roman Reinfuss sformułował argument mający w zamyśle stępić krytyczne ostrze argumentacji Obrębskiego, dowodząc możliwości pogodzenia ze sobą analizy przestrzennej - obiektywnej - dystrybucji cech kulturowych z subiektywnym poczuciem przynależności do określonej grupy. Reinfuss wsparł się tu autorytetem innego etnografa (i późniejszego socjologa) Kazimierza Dobrowolskiego, wytrawnego badacza społeczności karpackich, który usiłował pogodzić w swojej koncepcji grup etnograficznych subiektywne i obiektywne kryteria przynależności grupowej, czyli poczucie odrębności względem innych grup oraz obiektywną dystrybucję przestrzenną określonych cech inwentarza tworzących kulturowe terytorium danej grupy (Dobrowolski, 1938, ss. 201-203). Reinfuss, sam zajmujący się etnogeografią i kartografią etnograficzną, chciał w ten sposób dowieść, że argument Obrębskiego nie podważa mimo wszystko dotychczasowej praktyki wytyczania granic między grupami według dystrybucji przestrzennej cech kulturowych (Reinfuss, 1998, s. 14).

W kolejnych latach również inni badacze omawiali pogląd Obrębskiego jako rzekomo zgodny z ideą wytyczania granic grupowych w oparciu o analizę etnogeograficzną (Kantor, 1989; Pokropek, 1979). Zofia Staszczak, zajmująca się mapowaniem granicy polsko-niemieckiej, wskazała natomiast na „niepoprawność” posługiwania się proponowanym przez Obrębskiego kryterium świadomościowym w kontekście badań pogranicza międzyetnicznego (jego zasadność miała się ograniczać do badania granic wewnętrznych). Subiektywne deklaracje samoidentyfikacyjne mogły być, jej zdaniem, przedmiotem manipulacji politycznej władz niemieckich (Staszczak, 1978, ss. 73-74).

Argumentacja przedstawiona przez Obrębskiego nie pozostawiała wątpliwości, że tylko subiektywne poczucie przynależności do grupy może stanowić kryterium przynależności i odrębności grupowej. Z napięcia między koncepcjami Obrębskiego a ideami etnogeografii zdawała sobie najpewniej sprawę komentująca jego poglądy Anna Kutrzeba -Pojnarowa, pisała bowiem: „(...) Wszyscyśmy zresztą w tym samym okresie przysięgali na Obrębskiego i na jego studia. Nie było to jednakże wtedy jednoznaczne z podjęciem pytań przez niego stawianych" (Kutrzeba-Pojnarowa, 1979, s. 75). Omawiając zarzuty Obrębskiego wobec wykorzystania metody mapowania do wytyczania granic etnicznych, Zbigniew Benedyktowicz słusznie zauważył, że stanowisko tego pierwszego „(...) bardzo odbiegało od modelu uprawianej wówczas etnografii", nie znajdując w niej właściwego oddźwięku (Benedyktowicz, 2000, ss. 28-31).

Problematykę Obrębskiego - za sprawą starań Kutrzeby-Pojnarowej, a później Anny Engelking - udało się jednak podjąć na nowo kolejnym generacjom etnolożek i etnologów. Kutrzeba-Pojnarowa uczestniczyła w roku 1973 w wystawie zorganizowanej w Amherst w Stanach Zjednoczonych, na której przedstawiono fotografie wykonane przez Obrębskiego podczas badań na Polesiu. Niedługo przed śmiercią powierzyła zaś etnolożce i slawistce Annie Engelking ideę opracowania i publikacji materiałów terenowych Obrębskiego. Dzięki ogromnej pracy Engelking kluczowe teoretyczne teksty ukazały się zwartym drukiem w 2005 roku. Dwa lata później - w opracowaniu naukowym tej samej autorki wydano prace dotyczące Polesia (Obrębski, 2007). Obecnie trwają prace nad krytyczną edycją materiałów zgromadzonych przez Obrębskiego podczas badań w regionie Porecza w Macedonii. 
Innym, oprócz koncepcji grup i zróżnicowań etnicznych wkładem Obrębskiego w badania dotyczące stosunków narodowościowych i etnicznych był oparty na badaniach poleskich teoretyczny zarys procesów unaradawiania mas ludowych, przedstawiony zarówno w opublikowanych za jego życia artykułach, jak i bogatych i niezwykle ciekawych materiatach wydanych pośmiertnie.

Przedstawiając swą koncepcję, Obrębski był jak najdalszy od twierdzenia, że proces unaradawiania (który na Polesiu dopiero się wówczas zaczynał) trzeba rozumieć jako uaktywnienie czy pobudzenie w świadomości ludzi obecnej już u nich cechy. Zdaniem Obrębskiego jest dokładnie na odwrót. Uważa on mianowicie, że unarodowienie jest procesem wytworzenia określonego poczucia przynależności/odrębności narodowej w pewnych grupach społecznych w efekcie podjętego przez aparaty władzy i grupy narodowe określonych działań asymilacyjnych i integracyjnych. Unarodowienie społeczności ludowych traktuje się tu jako ważny aspekt procesu narodotwórczego w ogóle. Nie chodzi bowiem o proste dołączenie nowej zbiorowości do już istniejącej społeczności narodowej, ale o ciągły proces przemian całej grupy narodowej zachodzący w wyniku unaradawiania nowych zbiorowości. Asymilacja społeczności ludowych przez grupy narodowe nie jest też nieuchronna i zależna jedynie od aparatu władzy państwowej. Społeczności ludowe mogą zarówno przyswajać określone idee narodowe i włączać się w jakąś grupę narodową, jak również są w stanie opierać się temu procesowi i separować względem grupy dążącej do unarodowienia.

Obrębski wprowadza do rozważań perspektywę etnografa. Wyróżnia ją to, że dyskusja o unarodowieniu zostaje osadzona w kontekście lokalnym. Uwage zwraca się na specyficzne instytucje, praktyki i działania mające na celu nacjonalizowanie ludności. Prace Obrębskiego pokazują przy tym fiasko akcji polonizacyjnej na Polesiu oraz głębsze uwarunkowania tych politycznych niepowodzeń. Analizy te można określić jako przykład etnografii ideologii narodowych, ukazującej działania i praktyki, poprzez które ideologia narodowa jest praktykowana, przyswajana i kontestowana w wiejskim środowisku Polesia.

Obrębski dowodzi, że sanacyjna polityka unaradawiania doprowadziła nie do integracji i asymilacji Poleszuków, lecz separowania miejscowej ludności. Antagonizm stanowy między polską szlachtą a poleskimi chłopami ustępuje w czasach II Rzeczypospolitej konfliktowi między polską administracją państwową a poleskimi społecznościami lokalnymi. Konflikt ów miał wedle Obrębskiego podstawy w różnicach klasowych. Miejscowa administracja i personel innych instytucji publicznych rekrutowały się wyłącznie spośród Polaków, którzy jako grupa „(...) panów, podpanków i rządzących” (Obrębski, 2007, s. 295) silnie podkreślali swą społeczno-kulturową odrębność względem wsi i jej mieszkańców. Obrębski opisuje ów „pański” sposób bycia Polaków w stosunku do mieszkańców Polesia. Wyrażał się on w poczuciu klasowej i etnicznej wyższości elementu polskiego, częstym i dobitnym podkreślaniu w tej zbiorowości odrębności polskiego stylu życia, przy jednoczesnym przekonaniu o „polskiej misji cywilizacyjnej na prymitywnym dzikim Polesiu" (Obrębski, 2007, ss. 535-536).

Ilustracji obrazujących relacje polsko-poleskie dostarcza znakomita rozprawa Pańska szkoła i mużyckie dzieci dotycząca szkoły powszechnej we wsi Olmany. Badacz ujawnia nie tylko postawy konkretnych nauczycielek i nauczycieli (część z nich odnosiła się do ludności wsi z szacunkiem, inni demonstrowali swą pogarde i wyższość, uciekając się do przemocy i gwałtu). Analiza uwidacznia również nieprzystawalność programu szkolnego 
do doświadczenia życiowego młodego pokolenia wsi, a także swego rodzaju obojętność miejscowych wobec pewnych działań i praktyk związanych z polonizacją. Ciekawy jest tu przykład zorganizowanej przez szkołę procesji okolicznościowej błądzącej „[...] z chorągiewkami po pustych ulicach wsi w rocznice 3 maja [...]" (Obrębski, 2007, s. 421), skontrastowany z radośnie obchodzonymi przez dzieci wiejskie wiosennym świętem krasnej, o którym z kolei nic nie wiedzą władze polskiej szkoły (Obrębski, 2007, s. 423).

Faktycznie społeczne wykluczenie Poleszuków wspótistniało jednak z widocznym w tej grupie dążeniem do naśladowania owego pańskiego stylu życia i pragnieniem awansu społecznego. W tej sprzeczności dostrzegał Obrębski źródła niepowodzenia polityki unaradawiania, czyli tzw. „akcji polskiej” na Polesiu. Miejscowa ludność uznawała za właściwe i naśladowała wzory pańskiego stylu życia podtrzymywane i kultywowane przez polsko-pańską klasę dominującą, a jednocześnie nie była przez Polaków dopuszczana do przynależności do owej klasy na równych prawach, co wywoływało u Poleszuków poczucie krzywdy i upokorzenia (Obrębski, 2007, s. 296).

Studia poleskie Obrębskiego oferują nam wgląd w mechanizmy procesów unaradawiania. Uznani teoretycy nacjonalizmu dowodzili później, że upowszechnienie ideologii nacjonalistycznych na całe populacje zamieszkujące w państwach narodowych jest nieuchronną konsekwencją procesów modernizacji (Anderson, 1997; Gellner, 1991; Hobsbawm, 2010). A zatem nacjonalizm jest ostatecznie siłą integrującą i ujednolicającą pod względem kulturowym zbiorowości żyjące w granicach zarządzanych przez nowoczesne aparaty władzy. Pogląd ten legł również u podstaw koncepcji współczesnych Obrębskiemu polskich socjologów narodu, takich jak Chałasiński, Ossowski czy Nowakowski. Czy rzeczywiście? Obrębski zwraca uwage na drugą stronę procesu unarodowienia, czyli to, że efektem nacjonalizacji mas ludowych może być również społeczne wykluczenie i kulturowa dysymilacja lokalnych populacji, innymi słowy "zamykanie się na zewnątrz" - używając terminu Maxa Webera (M. Weber, 2002, s. 32) - na określone inne grupy i zbiorowości, co prowadzi w efekcie do wytwarzania zjawiska narodowej większości i mniejszości, a także specyficznej relacji większość - mniejszość (por. Gladney, 1998).

Obrębski pokazuje także, że przebiegu procesów asymilacji i dysymilacji nie można tłumaczyć po prostu odmiennościami kulturowymi między grupą narodową a określoną populacją ludową lub regionalną. Same w sobie różnice kulturowe nie wyjaśniają, jego zdaniem, skali i głębokości konfliktu między polską administracją a mieszkańcami Polesia. Trzeba zwrócić uwagę na sposób działania i organizacji całego aparatu polityki nacjonalizacji w różnych dziedzinach życia społecznego (administracji, sądownictwie, gospodarce, edukacji, polityce) oparty, jak powiada badacz, na kultywowaniu „wyłączności klasowej” hamującej skutecznie proces asymilacji odmiennych klasowo grup (Obrębski, 2007, s. 287).

Studia Obrębskiego pokazują także, że nacjonalizm jest nie tylko wyobrażeniem, ideą, wartością czy ideałem, „ojczyzną ideologiczną” jakby powiedział Stanisław Ossowski, ale pewnym rodzajem społecznej praktyki, kompleksem modalności działania społecznego lub jak powiada sam autor „czynnością narodową” (Obrębski, 2007, s. 527). Poczucie odrębności/przynależności narodowej, czyli tożsamość narodową, można zatem, podążając tym tropem uznać nie za świadomą identyfikację z całokształtem treści składających się na tzw. kulturę narodową, lecz uświadomiony skutek zaangażowania lub jego braku w określone praktyki i specyficzne struktury organizacyjne.

Godnym uwagi jest to, że opracowana przez Obrębskiego koncepcja procesów unaradawiania nie spotkała się jednak z większym zainteresowaniem wśród współczesnych mu socjologów zajmujących się stosunkami narodowościowymi. Ani współpracujący 
z Obrębskim przed wojną Józef Chałasiński, ani inni badacze owego czasu, tacy jak Stefan Nowakowski czy Stanisław Ossowski, nie odwoływali się w swoich empirycznych pracach do rozważań Obrębskiego, pozostawali z nim jednak po wojnie w osobistym kontakcie (Engelking, 2003, s. 39).

Przyczyn owej absencji Obrębskiego w kanonicznych pracach z zakresu socjologii narodu można upatrywać zarówno w tym, że po wojnie pozostawał on na marginesie polskiej nauki instytucjonalnej, jak też w niedostrzeganiu przez jego współczesnych teoretycznego znaczenia jego poleskich opracowań. Reprezentanci socjologii narodu operowali siatką pojęciową, którą Obrębski sam przyjmował połowicznie. Jego własny sposób widzenia procesów unaradawiania nie przystawał do analiz opartych na kategoriach grup, mas i żywiołów etnicznych jako bytów zbiorowych, więzi społecznych, odrębnych narodowych czy regionalnych kultur oraz integracji narodowej. Myśląc o procesach unaradawiania w terminach subiektywnego poczucia odrębności, wyobrażeń, stereotypów, sprawstwa i konkretnych działań oraz ujmując unarodowienie jako proces otwarty, potencjalnie wielokierunkowy, Obrębski nie mógł, jak się zdaje, „przemówić teoretycznie” nawet do grona badaczy, z którymi pozostawał skądinąd w dość ścisłych naukowych i koleżeńskich relacjach. Spróbuję to pokazać, porównując jego analizy do wybranych studiów czołowych przedstawicieli socjologii narodu należących do jego pokolenia.

Rok przed opublikowaniem przez Obrębskiego serii tekstów na temat unarodowienia i etniczności, Józef Chałasiński opublikował na łamach „Przeglądu Socjologicznego" wyniki swego sześciotygodniowego pobytu badawczego w górniczym osiedlu Murcki koło Katowic (określonym w artykule jako „Kopalnia”) na Górnym Śląsku (Chałasiński, 1935). Tematem Chałasińskiego był antagonizm polsko-niemiecki. Zarówno Obrębski, jak i Chałasiński byli świadomi znaczenia studiów nad procesami unaradawiania, dostrzegając sprzeczności i dyskryminację, jakie integracja populacji w oparciu o upowszechnianą przez państwo ideologię narodową mogą przynosić. Niemniej, zestawienie studium Chałasińskiego z opublikowanymi tylko rok później tekstami Obrębskiego pokazuje różnice między tymi autorami.

Chałasiński spoglądał na relacje w osiedlu górniczym jako stosunek pomiędzy dwiema odrębnymi grupami narodowymi (polską i niemiecką), mimo iż jego własne dane pokazywały, że sytuacja na miejscu jest znacznie bardziej złożona. Przede wszystkim poczucie przynależności etnicznej robotników nie zamykało się w prostym podziale na Polaków i Niemców, którym posłużył się badacz. Chałasiński użył mylącego „obiektywnego" kryterium językowego jako probierza polskości lub niemieckości (Chałasiński, 1935, s. 159). Tymczasem samoidentyfikacje narodowe i etniczne zamieszkujących osiedle górniczych rodzin bywały znacznie bardziej zróżnicowane. Część z nich nie chciała określać się w kategoriach narodowościowych. W gruncie rzeczy napięcia na tle narodowościowym wcale nie odgrywały w osiedlu roli, jaką z założenia przypisał im Chałasiński. Istotniejszy okazał się konflikt klasowy, który przecinał się z podziałami narodowościowymi, a także lokalne waśnie partyjne. Poza tym więzy i formy współpracy w lokalnej społeczności tworzono również w poprzek postulowanych przez Chałasińskiego "bloków narodowych" (Chałasiński, 1935, ss. 230-231).

Chałasiński nie był w stanie ukazać mechanizmów alienacji miejscowej ludności, które w badaniach na Polesiu rozpoznat i wnikliwie analizował Obrębski, ponieważ nie brał pod uwagę, że czynnikiem wykluczenia może być sama ideologia nacjonalistyczna i sposób działania polskiego aparatu władzy. W istocie Chałasiński ujmował procesy nacjonalizacji mas ludowych bardziej jako zadanie do wykonania, które uczony może poznawczo wesprzeć, niż jako przedmiot kompleksowej i nieuwikłanej w ideologię narodową analizy. 
Przekonują o tym również jego powojenne prace dotyczące procesów integrowania narodu polskiego (Chałasiński, 1968, 1969, 1988).

Obrębski nie był wolny od zaangażowania politycznego, jego analizy zdradzają przecież wyraźną u postępowego inteligenta niechęć do ostentacyjnie pańskiego sposobu bycia Polaków na Polesiu (w szczególności drażnił go styl życia podpanków), niemniej pozostawał daleko bardziej otwarty na świadectwa empiryczne, które sprawiały kłopoty pojęciowe uczonym przyjmującym bez cienia krytyki ramy pojęciowe wspieranej przez państwo ideologii narodowej.

Bardziej subtelny sposób analizowania procesów unaradawiania zawdzięczamy Stanisławowi Ossowskiemu, który w 1947 roku opublikował obszerny artykuł oparty na krótkich badaniach przeprowadzonych przez niego wraz z asystentami rok i dwa lata wcześniej we wsi Dobrzeń Wielki (nazwanej w pracy Giełczynem) koło Opola, należącej historycznie do Górnego Śląska, włączonej do Polski po II wojnie światowej (Ossowski, 1967). Ossowski odrzuca prosty podział ludności wedle kategorii narodowych, dowodzi wprost, że to poczucie przynależności do wspólnoty regionalnej jest dla miejscowych Ślązaków znacznie ważniejsze niż przynależność do polskiej czy niemieckiej wspólnoty narodowej. To identyfikacja z regionem i jego kulturą stanowi tu, jak pisze Ossowski, ojczyznę ideologiczną. Badacz studiuje sposoby funkcjonowania różnych kategorii i klas społecznych żyjących w społeczności w zmieniających się warunkach ekonomicznych i politycznych, śledzi strategie tożsamościowe mieszkańców a także poważne napięcia między miejscowymi a nowo przybyłymi z innych obszarów repatriantami w okresie powojennym.

Studium Ossowskiego opiera się jednak na założeniu, że włączenie całości Śląska do Polski po 1945 roku jest spotkaniem dwu różnych wspólnot wyobrażonych, czyli dokładniej dwu odmiennych podzielanych przez różne zespoły ludzkie obrazów wspólnoty, z których jedna to istniejąca od dawna śląska grupa regionalna, druga zaś - w obecnej chwili dominująca - polska grupa narodowa. Skądinąd bardzo cenne rozróżnienie między rzeczownikowym a przymiotnikowym sensem określenia „Polak”, z jakim spotkał się Ossowski podczas prowadzenia badań (Ossowski, 1967, ss. 263-266), nie skłoniło badacza do potraktowania unarodowienia jako działań już nie mas, żywiołów czy wielkich grup narodowych, ale również konkretnych ludzi podejmujących, jak by powiedział Obrębski, „czynności narodowe”.

Argumentację zarysowaną w szkicu Ossowskiego rozwija i pogłębia Stefan Nowakowski, pomagający na początku Ossowskiemu, a następnie samodzielnie kierujący badaniami zarówno w Dobrzeniu jak i w niewielkim wówczas mieście Kędzierzynie-Koźlu na Śląsku Opolskim (zob. Sołdra-Gwiżdż, 2010). Jak Chałasiński podejmował badania w Murckach, przyjmując z góry założenie o antagonizmie polsko-niemieckim, tak Nowakowski trzyma się w swoich studiach konsekwentnie założenia, iż proces narodotwórczy na Śląsku prowadzi w ostatniej instancji do integracji śląskiej grupy regionalnej z narodem polskim i ujednolicenia kulturowego żyjących na Śląsku po wojnie grup, czyli autochtonów i różnych kategorii nowo przybyłych do regionu Polaków (Nowakowski, 1957, 1960). Analizy Nowakowskiego przynoszą wiele niezwykle interesujących i wnikliwych obserwacji. Mowa jest o krzywdach i upokorzeniach, które spotkały Ślązaków po II wojnie światowej.

Autor ten operuje jednocześnie aparatem pojęciowym przedstawiającym proces narodotwórczy jako nieuchronne stapianie w jedno grup społecznych, tworzenie się ponadlokalnej więzi i jednolitej kultury narodowej, pozwalających na integrację grup regionalnych ze wspólnotą narodową. Program integracji narodowej realizowany na różnych polach aktywności przez aparat państwowy może wszakże prowadzić - jak to miało miejsce na Śląsku w okresie socjalizmu państwowego - do pogłębiania dysymilacji i wyklucza- 
nia przynajmniej pewnych frakcji społeczności regionalnej. Trudno byłoby powiedzieć, że Nowakowski w ogóle nie zauważał napięć między grupami (zob. Nowakowski, 1957, ss. 8-69), niemniej traktował zjawisko dysymilacji Ślązaków jako sytuację przejściową, ignorując fakt, że realizowany przez władze w różnych dziedzinach program unaradawiania wyobcowywał część śląskiej społeczności regionalnej. Przykładowo: walkę z językiem śląskim, obniżanie autorytetu tego języka badacz uznawał za pozytywny wskaźnik ujednolicenia kulturowego.

Można zasadnie utrzymywać, że proponowana przez Obrębskiego koncepcja unarodowienia odbiega w pewnym stopniu od stanowiska prezentowanego przez wspomnianych wyżej badaczy stosunków narodowościowych. Po pierwsze, wedle Obrębskiego punktem wyjścia analizy jest nie zbiorowy byt zwany narodem, grupą etniczną czy grupą etnograficzną, lecz subiektywne poczucie przynależności do określonej grupy oraz odrębności względem innych grup. Po drugie, unarodowienie to proces, na który należy spoglądać nie przez pryzmat więzi społecznej, podzielanych przez ludzi ideologii i wspólnej kultury, lecz czynności narodowych, specyficznych działań aparatu władzy, organizacji i stowarzyszeń a nawet pojedynczych osób na rzecz asymilacji i integracji społeczności ludowej z innymi segmentami społeczeństwa narodowego. Po trzecie, unarodowienie nie jest procesem nieuchronnie wiodącym do integracji społecznej i kulturowego ujednolicania grup narodowych, lecz może prowadzić do dysymilacji i wykluczenia określonych zbiorowości.

Rok po śmierci Obrębskiego młody socjolog Włodzimierz Pawluczuk wykorzystał jego ujęcie w badaniach mniejszości białoruskiej na Białostocczyźnie (Pawluczuk, 1968). Podobnie jak Obrębskiego Pawluczuka interesowała problematyka grup etnicznych i unaradawiania w społecznościach ludowych. „(...) W literaturze polskiej - pisał Pawluczuk - nikt - jak się wydaje - nie scharakteryzował lepiej specyfiki świadomości etnicznej jak Józef Obrębski w swym studium Problem grup etnicznych w etnologii i jego socjologiczne ujęcie (...)" (Pawluczuk, 1968, s. 38). Analiza Pawluczuka ukazuje rolę katolicyzmu i prawosławia w procesie polonizacji mówiącej po białorusku katolickiej ludności regionu oraz wyłaniania się - na bazie przynależności religijnej do prawosławia - mniejszości białoruskiej w Polsce (por. Pawluczuk, 1972).

Pierwszym bardziej systematycznym socjologicznym omówieniem idei Obrębskiego pozostaje prawdopodobnie tekst Stefana Nowakowskiego opublikowany W "Kulturze i Społeczeństwie" w 1982 roku pod wymownym tytułem Józef Obrębski - socjolog niedoceniony (Nowakowski, 1982). W artykule padają słowa o ogromnym teoretycznym bogactwie, metodologicznej oryginalności jego prac. Nowakowski nie próbował jednak zestawiać w swoim omówieniu koncepcji Obrębskiego z badaniami nad procesami unaradawiania, jakie prowadzili on sam, a także Ossowski, Chałasiński i Znaniecki. Nie powołał się również na analizy Pawluczuka, który wykazał na przykładzie wyłaniania się mniejszości białoruskiej w Polsce użyteczność koncepcji unaradawiania proponowanej przez Obrębskiego (Nowakowski, 1982).

Ani świetne studium Pawluczuka, ani podjęty pod koniec życia przez Nowakowskiego wysiłek prezentacji wyników badań poleskich nie zmienia faktu, że prace Obrębskiego nie weszły do ścisłego wąskiego kanonu dzieł polskiej socjologii narodu. Znajdują się - owszem - w kanonie szerokim, na długiej liście tekstów kilkudziesięciu znaczących postaci świata polskiej socjologii, etnologii. Wypada żałować, że jego analiza dynamiki unarodowienia wpływała jedynie w ograniczonym stopniu na rozwijające się intensywnie w Polsce socjologiczne, etnologiczne i historyczne badania obszarów pogranicza oraz teorię stosunków narodowościowych i etnicznych. 
Mam nadzieję, że udało się pokazać, na czym polegał realizowany w pracach Obrębskiego przełom myślowy w badaniach etnicznych i narodowościowych. Czy jednak idee tego badacza, nawet jeśli ujawni się ich niegdysiejszą wywrotowość, są wciąż dla nas aktualne i przydatne?

Trzeba jasno stwierdzić, że siłą tej myśli jest jej otwartość, jest ona w stanie ukierunkowywać nasze dociekania, nie narzucając zarazem jednego jedynie słusznego toku rozumowania. Stwarza ona kolejnym generacjom nowe możliwości poszukiwań badawczych nie proponując ostatecznych rozwiązań. Nie był więc Obrębski ani prorokiem głoszącym zupełnie nową wizję rzeczywistości, ani niezrozumianym przez innych outsiderem. Pozostaje inspirującym rozmówcą, którego idee pobudzają do nowych studiów i rozważań, poszerzając stopniowo chociaż nie nazbyt śpiesznie nasz ogląd procesów narodowościowych i stosunków etnicznych.

Aktualność jego koncepcji może się objawiać wielorako. Prace Obrębskiego stanowią zachętę dla wszystkich badań, w których pojęcia własne badacza/badaczki traktuje się ze sceptycyzmem i krytycznie, zważywszy na to, że celem analizy jest w pierwszej kolejności poznanie świata doświadczeń, pojęć i praktyk ludzi, wśród których badania są prowadzone. Obrębski doskonale zdawał sobie sprawę z faktu, że badacze nierzadko podchodzą do analizy z gotową siatką pojęć, ustalonymi klasyfikacjami i kategoryzacjami ukształtowanymi w toku określonej socjalizacji i edukacji narodowej, czymś co nazwał on "narodowo zorientowaną kategoryzacją świata społecznego" (Obrębski, 2007, s. 301). Narody i podziały między nimi są w myśl takiej kategoryzacji realnościami tak oczywistymi i powszechnymi, że wszelkie inne formy życia w grupach rozpatruje się co najwyżej jako przed-narodowe lub post-narodowe. Tymczasem pytanie o przynależność do takiej czy innej narodowej kategorii lub grupy zawsze może okazać się dla ludzi irrelewantne. Celem rozważań winno być natomiast możliwie jak najbardziej dogłębne poznanie dychotomii i kategoryzacji używanych przez samych uczestników/uczestniczki życia społecznego w różnych jego kontekstach i domenach. Co więcej, należy również śledzić dynamikę i niejednoznaczność tych dychotomii i kategoryzacji.

Nie może przeto dziwić, że przydatność ujęcia Obrębskiego wykazano najpierw w etnologicznych badaniach dotyczących tożsamości zbiorowych. W tym kontekście jego idee i postulaty rozwija Anna Engelking, prowadząca badania w społecznościach kołchozowych na Białorusi. Łącząc kompetencje językoznawcze i etnograficzne, Engelking studiowała tożsamości przez pryzmat potocznych kategoryzacji, którymi operowali na co dzień jej rozmówcy/rozmówczynie. Jej analizy poświęcone kategorii nacji-podobnie jak kiedyś studia Obrębskiego - stanowią znakomity punkt odniesienia dla wszelkiej refleksji ukazującej pojęciowe ograniczenia, jakie narzuca nam socjalizacja i edukacja w obrębie określonej ideologii narodowej. Tylko porzucając własne zdroworozsądkowe rozumienie pojęć takich jak katolicyzm, polskość czy białoruskość, badacz/ka jest w stanie zrozumieć sposoby myślenia i działania kołchoźników, ich idee dotyczące religii, narodowości, poczucia przynależności do lokalnej zbiorowości, codziennej komunikacji, władzy, oporu i życia w warunkach kołchozowych w ogóle (zob. Engelking, 1995, 1996, 2007a, 2012b).

Idea, w myśl której grupy należy ujmować jako twory wyobrażeniowe oparte na subiektywnym poczuciu odrębności względem innych grup, pozwala nam dokładniej i wszechstronniej śledzić procesy formowania, wielopostaciowości, przemian, a także rozpadu grup etnicznych. Uwalniając się od pojęć takich jak więź grupowa czy kultura etniczna, można 
- podążając za Obrębskim - analizować grupowość in statu nascendi jako konkretne sposoby działania i relacje, a nie abstrakcyjny etniczny substrat życia grupowego (por. Brubaker, 2004).

Analiza opozycji między wizerunkami grupy obcej i własnej, badanie stereotypów etnicznych czy ogólniej grupowych pozwala wejrzeć w dynamikę relacji i współzależności między grupami nie tylko z perspektywy współczesnej, ale również w szerszym kontekście historycznym. Badania Engelking dotyczące kołchoźników na Białorusi wskazują na zaskakującą historyczną żywotność opozycji konstytuujących tożsamość zbiorową tej grupy, czyli opozycji chłop - pan oraz chłop - Żyd stanowiących, jak pisze autorka, pojęciowe szufladki domagające się nieustannego wypełnienia bieżącymi treściami życia społecznego (Engelking, 2012b, s. 454). Opozycje te i konstytuowane przez nie relacje w miarę upływu czasu ulegają transformacjom: podział na chłopów i panów zastępuje opozycja kołchoźnicy - dyrektor kołchozu (predsiedacieh, w miejsce kontrastu chłopi - Żydzi, powstaje przeciwstawność pozbawionych władzy ludzi ze wsi i znajdujących się jej blisko ludźmi z miast (Engelking, 2012b, ss. 156-174, 477-481).

Jak zauważyła z kolei Justyna Straczuk, antropolożka odwołująca się również do dorobku Obrębskiego, podział na obcych i swoich może być względny, zależny od kontekstu interakcyjnego albo specyficznej domeny życia społecznego. Tym samym Straczuk wskazuje, że przedmiotem analizy winno być postrzeganie, zaznaczanie i rozmywanie różnic kulturowych w określonych sytuacjach społecznych (Straczuk, 2006, s. 33). Taka analiza może być punktem wyjścia do rozważań na temat dynamiki poczucia odrębności/przynależności stanowiących podłoże wyodrębniania grup etnicznych lub - przeciwnie - zacierania granic między grupami etnicznymi.

Etnograficzna analiza procesów unaradawiania jest, jak można sądzić, inną jeszcze dziedziną studiów, na którą praca Obrębskiego rzuca niezmiernie ciekawe światło. Niezwykle inspirującym wskazaniem ze strony tego badacza jest ujmowanie unaradawiania jako zbioru czynności, ucieleśnionych aktywności, a nie tylko jako przemiany w obrębie społecznego imaginarium. W unaradawianiu widzi Obrębski proces, na który składa się wiele powiązanych ze sobą i zorganizowanych przestrzennie działań, włączając w to również podejmowany przez aparat władzy wysiłek osobliwego osadzenia istniejących praktyk, nawyków, obyczajowości społeczności ludowych w ramach ideologii narodowych. Z proponowanej przez tego badacza perspektywy nacjonalizm to nie jednakowo wszędzie rozumiana idea ojczyzny ideologicznej, lecz konkretne postawy i zachowania nauczycieli w szkole powszechnej, sędziów, leśniczych, właścicieli ziemskich czy osławionych „podpanków". Ideologia, jak pokazuje Obrębski, realizowana jest nie poprzez abstrakcyjne oderwane od kontekstu symbole czy teksty, lecz inicjowane przez organizacje czy zbiorowości obrzędy, uroczystości, rozrywki, procedury, wydarzenia i akty, jak również modus operandi poszczególnych osób, czyli ogólniej ujmując, cielesne praktyki określonych osób i środowisk w danym miejscu i czasie.

Świetny obraz praktyki ideologicznej kreśli Obrębski, analizując fenomen popularności na Polesiu komunistów w niedokończonej pracy Dzisiejsza wieś poleska:

(...) W odróżnieniu od zwykłych inteligentów są oni [komuniści] przystępni; nie separują się od ludności odmiennością etykiety, stroju, potrzeb, aspiracji kulturalnych (...) Nie zaznaczają swojej odrębności klasowej, lecz na każdym kroku podkreślają swoją przynależność i solidarność klasową. Stan ujemny chłopstwa tłumaczą nie osobistymi niedoborami psychicznymi [czy] kulturalnymi [chłopów], lecz działaniem czynników zewnętrznych, [takich jak] ucisk klasowy, celowa akcja rządu itp. (...) Ich stosunek do innych [jest] bezinteresowny, pozbawiony momentów utajonej zawiści [i] niechęci na tle rywalizacji o stanowiska i wpływy wiejskie (...) Największe 
uznanie znajduje nie komunista-teoretyk - ideolog, lecz demagog tzn. ten, który aspiracje, koncepcje, bolączki [i] żądania ludności przyjmuje jako podstawę programu komunistycznego (...) (Obrębski, 2007, s. 520).

Fragment ten, jak wiele innych, pokazuje czynnościowe podejście Obrębskiego do analizy ideologii. Nacjonalizm, komunizm czy inne ideologie są tu traktowane jako jeden z mechanizmów społecznej reorganizacji wsi w warunkach głębokich przemian społeczno-ekonomicznych. Jednocześnie Obrębski jak nikt inny spośród polskich badaczy procesów narodowościowych pokazuje unarodowienie jako proces potencjalnie dezintegracyjny, opresyjny i hierarchizujący. W tym względzie wchodzi Obrębski na grunt rozważań, które przyjęło się w dzisiejszych czasach wiązać z myślą postkolonialną oraz badaniami nad dominacją i oporem. Grażyna Borkowska (Borkowska, 2008, 2010) oraz Anna Engelking (Engelking, 2017) wykorzystują analizy tego autora celem ukazania orientalizacji wizerunku Poleszuka w polskiej literaturze i piśmiennictwie popularnonaukowym. Bez wątpienia opis tzw. akcji polskiej na Polesiu może z powodzeniem ilustrować praktyki segregacyjne analizowane w innych kontekstach przez krytyków kolonializmu (Fanon, 1967; Memmi, 2013). Rozważania Obrębskiego korespondują także z bardziej współczesną teorią postkolonialną spod znaku Subaltern Studies (Chatterjee, 1993; Chaturvedi, 2012; Guha, 2009).

Jak widać z powyższego, prace Obrębskiego to nie tylko świadectwo intelektualnej odwagi, przełamującej niegdysiejsze konwencje, i modalności dociekań, ale również świadectwo dociekliwości, rzetelności i pasji naukowej inspirującej kolejne pokolenia do dalszych badań i studiów.

Antropologiczna i socjologiczna refleksja nad etnicznością i nacjonalizmem przeszła oczywiście od czasów Obrębskiego bardzo znaczącą transformację. Krytyka esencjalizmu i dominacja ujęć procesualnych i konstruktywistycznych zdają się potwierdzać, iż sposób, w jaki myślał o grupach etnicznych i procesach nacjonalizacji Obrębski znalazł swe niezależne rozwinięcia zarówno w badaniach, jak i w refleksji teoretycznej (m.in. Banks, 1996; Eriksen, 2010; Jenkins, 2008; Kilias, 2004; Mach, 1993; Michna, 2004; Mucha, 1999; Nowak, 2000; Szmeja, 2000). Obecnie przyjmuje się na ogół bez większych zastrzeżeń, że narody czy etniczności to podlegające przemianom twory wyobrażeniowe, intencjonalne. Lepiej niż kiedyś zdajemy sobie również sprawę, że zróżnicowania i podziały na narodowe większości i mniejszości można wyprowadzić z analizy konkretnych ludzkich działań ideologicznych, a nie zastanych i niezmiennych różnic kulturowych, czy też sztywnych typologii relacji większość - mniejszość. Podobnie wiadomo nam, że owe działania i praktyki łączy immanentny związek z ludzkim dążeniem do władzy i uprzywilejowania względem innych. Dzięki analizom etnograficznym Józefa Obrębskiego wszystkie te stwierdzenia nabierają szczególnej konkretyzacji - stają się częścią czyjegoś ucieleśnionego doświadczenia, umiejscowionej emocji, konkretnej praktyki społecznej czy językowego wyobrażenia. Jednocześnie studia poleskie i etnograficzne relacje z Polesia sprzed ponad 80 lat dostarczają znakomitego przykładu rzetelności naukowej i podstawy do krytyki teorii, wskazując na istniejące w nich luki, uproszczenia, fałsz czy jednostronność. 
Anderson, B. (1997). Wspólnoty wyobrażone: Rozważania o źródłach i rozprzestrzenianiu się nacjonalizmu (S. Amsterdamski, Tłum.). Kraków: Wydawnictwo "Znak".

Banks, M. (1996). Ethnicity: Anthropological constructions. London: Routledge. https:// doi.org/10.4324/9780203417935

Barth, F. (2004). Grupy i granice etniczne: Społeczna organizacja różnic kulturowych. W M. Kempny \& E. Nowicka (Red.), Badanie kultury: Elementy teorii antropologicznej: Kontynuacje (ss. 348-377). Warszawa: Wydawnictwo Naukowe PWN.

Benedyktowicz, Z. (2000). Portrety "obcego": Od stereotypu do symbolu. Kraków: Wydawnictwo Uniwersytetu Jagiellońskiego.

Borkowska, G. (2008). Daleko od mitu: Kresy według Obrębskiego. Prace Filologiczne: Seria Literaturoznawcza, 55, 123-130.

Borkowska, G. (2010). Perspektywa postkolonialna na gruncie polskim: Pytania sceptyka. Teksty Drugie, 2010(5), 40-52.

Brubaker, R. (1992). Citizenship and nationhood in France and Germany. Cambridge, MA: Harvard University Press.

Brubaker, R. (2004). Ethnicity without groups. Cambridge, MA: Harvard University Press.

Burszta, W. J., Nowak, J., \& Wawruch, K. (Red.). (2002). Polska refleksja nad narodem: Wybór tekstów. Poznań: Wydawnictwo Poznańskie.

Bystroń, J. S. (1926). Wstęp do ludoznawstwa polskiego. Lwów: K.S. Jakubowski.

Bystroń, J. S. (1995). Megalomania narodowa. Warszawa: Wydawnictwo Książka i Wiedza (1 wyd. 1935).

Chałasiński, J. (1935). Antagonizm polsko-niemiecki w osadzie fabrycznej „Kopalnia” na Górnym Śląsku. Przegląd Socjologiczny, 3(1-2), 9-278.

Chałasiński, J. (1968). Kultura i naród: Studia i szkice. Warszawa: Książka i Wiedza.

Chałasiński, J. (1969). Rewolucja młodości: Studia o awansie mtodego pokolenia wsi i integracji narodu polskiego. Warszawa: Ludowa Spółdzielnia Wydawnicza.

Chałasiński, J. (1988). Tradycje i perspektywy przyszłości kultury polskiej. Warszawa: Ludowa Spółdzielnia Wydawnicza.

Chatterjee, P. (1993). The nation and its fragments: Colonial and postcolonial histories. Princeton, NJ: Princeton University Press.

Chaturvedi, V. (Red.). (2012). Mapping subaltern studies and the postcolonial. London: Verso.

Cohn, B. (1996). Colonialism and its form of knowledge: The British in India. Princeton, $\mathrm{NJ}$ : Princeton University Press.

Dobrowolski, K. (1938). Dwa studia nad powstaniem kultury ludowej w Karpatach zachodnich. W Studia Historyczne ku czci Stanisława Kutrzeby (T. 2). Kraków: Drukarnia Uniwersytetu Jagiellońskiego.

Engelking, A. (1995). Jak katolik to Polak: Co to znaczy?: Wstępne wnioski z badań terenowych na Białorusi. W A. Sadowski (Red.), Wschodnie pogranicze w perspektywie socjologicznej (ss. 138-146). Białystok: Wydawnictwo Ekonomia i Środowisko.

Engelking, A. (1996). Nacje to znaczy grupy religijne: O wynikach etnograficznych badań terenowych na Grodzieńszczyźnie. Kultura i Społeczeństwo, 40(1), 109-139.

Engelking, A. (2003). Cirriculum vitae of Józef Obrębski. W T. Vražinovski, A. Engelking, J. Halpern (Red.), 70 years from the research of Jozef Obrebski in Macedonian Poreche, 1932-1933 (ss. 25-44). Prilep: Institute for Slavonic Culture, Matica Makedonska. 
Engelking, A. (2005). Józef Obrębski - szkic do portretu w stulecie urodzin. W J. Obrębski, Dzisiejsi ludzie Polesia i inne eseje. A. Engelking (Red.) (ss. 9-24). Warszawa: Wydawnictwo Instytutu Filozofii i Socjologii PAN.

Engelking, A. (2006). Józef Obrębski - Etnolog i socjolog warszawski. Sprawy Narodowościowe, 2006(29), 91-107.

Engelking, A. (2007a). Old and new questions concerning Belarusian "local" identity. Sprawy Narodowościowe (Nationalities Affairs), 2007(31), 131-144.

Engelking, A. (2007b). Polesie Józefa Obrębskiego. W J. Obrębski, Studia etnosocjologiczne: T. 1. Polesie (ss. 9-32). Warszawa: Oficyna Naukowa.

Engelking, A. (2012a). Kazimierz Moszyński i Józef Obrębski: nauczyciel i uczeń. Lud, 96, 139-156.

Engelking, A. (2012b). Kołchoźnicy: Antropologiczne studium tożsamości wsi białoruskiej przełomu XX i XXI wieku. Toruń: Wydawnictwo Naukowe Uniwersytetu Mikotaja Kopernika.

Engelking, A. (2017) „Poleszuk” nieoswojony: Wokół funkcji chłopskości w konstruowaniu polskości. Teksty Drugie, 2017(6), 68-94.

Eriksen, T. H. (2010). Ethnicity and nationalism: Anthropological perspectives. London: Pluto Press.

Falkowski, J. (2006). Odpowiedź Jana Falkowskiego. Sprawy Narodowościowe, 2006(29), 171-172.

Falkowski, J., \& Pasznycki, B. (1935). Na pograniczu temkowsko-bojkowskiem: Zarys etnograficzny. Lwów: Towarzystwo Ludoznawcze.

Fanon, F. (1967). Black skin, white masks (R. Philcox, Tłum.). New York, NY: Grove Press.

Fischer, A. (1926). Lud polski: Podrecznik etnografii Polski. Lwów: Wydawnictwo Zakładu Narodowego im. Ossolińskich.

Gellner, E. (1991). Narody i nacjonalizm (T. Hołówka, Tłum.). Warszawa: PIW.

Gladney, D. (1998). Introduction: Making and marking majorities. W D. Gladney (Red.), Making majorities: Constituting the nation in Japan, Korea, China, Malaysia, Fiji, Turkey, and the United States. Stanford, CA: Stanford University Press.

Guha, R. (2009). Small voice of history: Collected essays. Ranikhet: Permanent Black.

Hobsbawm, E. (2010). Narody i nacjonalizm po 1780 roku: Program, mit, rzeczywistość (J. Maciejczyk \& M. Starnawski, Tłum.). Warszawa: Difin.

Jenkins, R. (2008). Rethinking ethnicity: Arguments and explorations. London: SAGE Publications.

Kantor, R. (1989). Kultura pogranicza jako problem etnograficzny. W Z. Jasiński, J. Korbel (Red.), Zderzenia i przenikanie kultur na pograniczach (ss. 239-252), Opole: Wyższa Szkoła Pedagogiczna im. Powstańców Śląskich.

Kilias, J. (2004). Wspólnota abstrakcyjna: Zarys socjologii narodu. Warszawa: Wydawnictwo IFiS PAN.

Kłodnicki, Z., Pieńczak, A., \& Koźmińska, J. (2017). Polski atlas etnograficzny: Historia, osiągnięcia, perspektywy badawcze. Katowice: Wydawnictwo Uniwersytetu Śląskiego.

Kuklick, H. (2008). Introduction. H Kuklick (Red.), A new history of anthropology. Oxford: Blackwell Publishing.

Kutrzeba-Pojnarowa, A. (1972). Pozycja Józefa Obrębskiego w etnografii polskiej. Etnografia Polska, 16(1), 215-219.

Kutrzeba-Pojnarowa, A. (1977). Kultura ludowa i jej badacze: Mit i rzeczywistość. Warszawa: Ludowa Spółdzielnia Wydawnicza. 
Kutrzeba-Pojnarowa, A. (1979). Wkład Józefa Obrębskiego w badania procesów etnicznych. Etnografia Polska, 23(2), 71-82.

Mach, Z. (1993). Symbols, conflict, and identity: Essays in political anthropology. New York, NY: Suny Press.

Malašević, S. (2013). Nation-States and nationalism: Organization, ideology and solidarity. Cambridge: Polity.

Merton, R. (1982). Teoria socjologiczna istruktura spoteczna (E. Morawska \& J. Wertenstein-Żuławski, Tłum.). Warszawa: Państwowe Wydawnictwo Naukowe.

Malkki, L. (1995). Purity and exile: Violence, memory, and national cosmology among Hutu refugees in Tanzania. Chicago, IL: University of Chicago Press. https://doi. org/10.7208/chicago/9780226190969.001.0001

Memmi, A. (2013). The colonizer and the colonized (H. Greenfeld, Tłum.). Plunkett Lake Press.

Michna, E. (2004). Kwestie etniczno-narodowościowe na pograniczu słowiańszczyzny wschodniej i zachodniej. Kraków: Polska Akademia Umiejętności.

Moszyński, K. (1967). Kultura ludowa Słowian (T. 1-3). Warszawa: Książka i Wiedza.

Mucha, J. (1999). Badanie stosunków kulturowych z perspektywy mniejszości. W J. Mucha (Red.), Kultura dominująca jako kultura obca (ss. 11-25). Warszawa: Oficyna Naukowa.

Nowak, J. (2000). Zaginiony świat: Nazywali ich Łemkami. Kraków: Universitas.

Nowakowski, S. (1957). Adaptacja ludności na Śląsku Opolskim. Poznań: Instytut Zachodni.

Nowakowski, S. (1960). Przeobrażenia społeczne wsi opolskiej. Poznań: Instytut Zachodni.

Nowakowski, S. (1982). Józef Obrębski - socjolog niedoceniony. Kultura i Społeczeństwo, 26(1-2), 3-20.

Obrębski, J. (2005). Dzisiejsi ludzie Polesia i inne eseje. Warszawa: Wydawnictwo IFiS PAN.

Obrębski, J. (2006). Recenzja książki Jana Falkowskiego i Bazylego Pasznyckiego Na pograniczu łemkowsko-bojkowskim. Sprawy Narodowościowe, 2006(29), 168-170.

Obrębski, J. (2007). Studia etnosocjologiczne: T. 1. Polesie. Warszawa: Oficyna Naukowa. Ossowski, S. (1967). Dzieła: T. 3. Z zagadnień psychologii społecznej. Warszawa: PWN.

Pawluczuk, W. (1968). Białorusini jako grupa etniczna - próba interpretacji socjologicznej. Studia Socjologiczne, 29(2), 35-50.

Pawluczuk, W. (1972). Światopogląd jednostki w warunkach rozpadu społeczności tradycyjnej. Warszawa: PWN.

Pokropek, M. (1979). Zróżnicowanie kulturowe na pograniczu etniczno-językowym i jego odbicie w świadomości mieszkańców na przykładzie pogranicza polsko-litewsko-białoruskiego w Polsce północno-wschodniej. Etnografia Polska, 23(2), 127-156.

Reinfuss, R. (1998). Łemkowie jako grupa etnograficzna. Sanok: Wydawnictwo Muzeum Budownictwa Ludowego w Sanoku (1 wyd. 1948).

Said, E. (2005). Orientalizm (M. Wyrwas-Wiśniewska, Tłum.) (2. wyd.). Poznań: Wydawnictwo Zysk i S-ka.

Scott, J. (1985). Weapons of the weak: Everyday forms of peasant resistance. New Haven, CT: Yale University Press.

Scott, J. (1990). Domination and the art of resistance: Hidden transcripts. New Haven, CT: Yale University Press.

Sołdra-Gwiżdż, T. (2010). Socjologia wobec Śląska - jedność czy wielość? Opole: Wydawnictwo Instytut Śląski. 
Staszczak, Z. (1978). Pogranicze polsko-niemieckie jako pogranicze etnograficzne. Poznań: Uniwersytet Adama Mickiewicza w Poznaniu.

Stocking Jr., G. (1968). Race, culture, and evolution. Essays in the history of anthropology. New York: The Free Press.

Straczuk, J. (2006). Cmentarz i stót: Pogranicze prawosławno-katolickie w Polsce i na Białorusi. Toruń: Wydawnictwo Naukowe Uniwersytetu Mikołaja Kopernika.

Szacki, J. (Red.). (1995). Sto lat socjologii polskiej: Od Supińskiego do Szczepańskiego: Wybór tekstów. Warszawa: Wydawnictwo Naukowe PWN.

Szmeja, M. (2000). Niemcy? Polacy? Ślązacy! Rodzimi mieszkańcy Opolszczyzny w świetle analiz socjologicznych. Kraków: Universitas.

Thomas, W., \& Znaniecki, F. (1976). Chłop polski w Europie i Ameryce (Z. Helsztyński i in., Tłum.) (T. 1-5). Warszawa: Ludowa Spółdzielnia Wydawnicza.

Weber, E. (1976). Peasants into Frenchmen: The modernization of rural France, 18701914. Stanford, CA: Stanford University Press.

Weber, M. (2002). Gospodarka i społeczeństwo: Zarys socjologii rozumiejącej (D. Lachowska, Tłum.). Warszawa: Wydawnictwo Naukowe PWN.

Williams, R. (2011). The long revolution. Cardigan: Parthian.

Wimmer, A. (2002). Nationalist exclusion and ethnic conflict: Shadows of modernity. Cambridge: Cambridge University Press. https://doi.org/10.1017/CB09780511490415

Wimmer, A., \& Glick-Schiller, N. (2002). Methodological nationalism and beyond: Nation-state building, migration, and the social sciences. Global Networks, 2(4), 301-334. https://doi. org/10.1111/1471-0374.00043

Wimmer, A. (2019). Nation building. Why some countries come together while others fall apart. Princeton: Princeton University Press.

Znaniecki, F. (1990). Współczesne narody. (Z. Dulczewski, Tłum.), Warszawa: PWN. 